\title{
Mobile Marketing: Applications And Implications For Physicians In Private Practice
}

Peter M. Resch, IQS School of Management, Barcelona, Spain Marta Tena, Ph.D., IQS School of Management, Barcelona, Spain

\begin{abstract}
The rapid proliferation of mobile technologies and mobile devices has resulted in an increase in the importance of mobile marketing and has captured the interest of academic researchers from a wide variety of disciplines. Due to its unique characteristics, mobile marketing is playing an increasingly significant role in marketing communication and Customer Relationship Management (CRM) efforts of organizations in various industries and professions. As mobile technologies and applications continue to evolve, the resulting opportunities for their increased use in the health care sector at large, and within specific sectors in the industry, are poised to increase significantly in coming years. Specifically, this paper explores the primary applications and implications of mobile marketing for physicians in private practice. Some of the key questions and challenges associated with the integration of mobile technologies by physicians in private practice are investigated and suggestions are made for future research directions.
\end{abstract}

Keywords: Mobile Marketing; Mobile Marketing Communications; mCRM; Physician-Patient Communication

\section{INTRODUCTION}

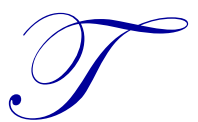

he rapid proliferation of mobile technologies and devices presents marketers of all industries and geographic regions with new and, in many cases, unique possibilities to reach out to their existing and potential customers. The advent of digital media has dramatically changed the way in which consumers interact with companies, the media, and each other (Winer, 2009). Mobile communication technologies have penetrated markets throughout the word, and thus mobile marketing is likely to have a strong influence on future business activities, consumer behavior, as well as on national and global markets (Dai \& Palvia, 2009). Mobile marketing has been defined as "the use of wireless media as an integrated content delivery and direct response vehicle within a cross-media or stand-alone marketing communications program" (Mobile Marketing Association, 2008). Mobile marketing is changing the way organizations communicate with their chosen target groups. While the use of mobile marketing channels has given rise to completely new forms of marketing, it also affects traditional media by making them interactive (Sharma, Herzog, \& Melfi, 2008, p. 107). The main goal of this paper is to explore the primary uses for mobile technologies and devices as a marketing communication tool for physicians in private practice.

A wide variety of companies such as airlines, banks, consumer products and pharmaceutical companies are increasingly capitalizing on the opportunities presented by mobile technologies and devices. As a result, mobile marketing expenditure is estimated to reach $\$ 20.0$ billion by 2015 (Gartner, 2011). Academic research on mobile marketing and its related subtopics is still considered nascent and scattered across disciplines (Shankar \& Balasubramanian, 2009). A number of literature reviews have been published to summarize and conceptualize research findings in the field and to identify future research opportunities (e.g. Drossos \& Giaglis, 2010; Shankar \& Balasubramanian, 2009; Varnali \& Toker, 2010). The use of mobile devices and technologies is finding increasing applications in different industries and has prompted industry-specific research such as in retail (Shankar, Venkatesh, Hofacker \& Naik, 2010), banking (Riivari, J., 2005; Cruz, Filgueiras Neto, Muñoz-Gallego \& 
Laukkanen, 2010), hospitality (Wang \& Wang, 2010), education (Scornavaca, Huff \& Marshall, 2009), or the pharmaceutical industry (BenMousa, 2010). However, for many companies, mobile marketing still represents a mysterious and challenging new component of a company's communication mix (Pousttchi \& Wiedemann, 2010). Many aspects of academic findings in this field are valid for a wide variety of industries and type of marketers, while other aspects are unique to specific sectors thus deserving specialized attention.

West and Blankenship (1975) noted more than three decades ago, that marketing concepts and physicians' professionalism are not incompatible in the pursuit of the patients' best interest. Van Doren and Blank (1992) claim that physicians are just as vulnerable to the laws of competition as any professional and thus those who learn to use the principles of marketing in a way that enhances health care will be the ones that benefit the most. Professional management and marketing in a changing health care environment is also perceived to offer physicians the opportunity to enhance the trust of their patients and build long-term relationships with them while maintaining a high quality of service (Letter, 2005). Whereas marketing should not be equated with promotion, it can contribute to the economic viability of a physician's practice, thus being the very pre-requisite to fulfill the physician's oath (Gehring \& Gehring, 2005). But is mobile marketing feasible for physicians in private practice?

This paper explores the primary uses for mobile technologies and devices as a marketing communication tool for physicians in private practice. It also reviews some of the key questions and challenges associated with the use of mobile marketing channels in the physician-patient communication and makes suggestions for future research work. In this study, mobile marketing is considered an emerging field of marketing communications consisting of advertising, sales promotion, direct marketing and customer relationship management as proposed by Leppäniemi and Karjaluoto (2008).

\section{MACRO DRIVERS}

The topic of mobile marketing in a private practice physician's context can be considered in the context of three macro drivers: the rise of mobile technology in the healthcare sector, the changing physician- patient relationship, and rising adoption rates of mobile devices and services by both physicians and their patients.

\section{Macro Driver \#1: The rise of mobile technology in the healthcare sector}

The emergence of mobile technologies and devices has given rise to the wider topic of mobile health (mhealth), which has been defined as the "emerging mobile communications and network technologies for healthcare" (Istepanian \& Lacal, 2003) or the medical and public health practice supported by mobile devices, such as mobile phones, patient monitoring devices, personal digital assistants (PDAs), and other wireless devices (World Health Organization, 2011). Mobile technologies and devices have been perceived to offer new possibilities and to possess the potential to address many of the healthcare challenges and demands of the twenty-first century (Goldberg \& Wickramasinghe, 2003) and to become an integral part of healthcare practice, management and processes (Han, Mustonen, Seppänen, \& Kallio, 2006). Wireless, handheld devices and systems have already started to change the ways of medical practice (Jokela et al., 2009). Mobile technologies are finding applications in both the administrative and the treatment side of healthcare. The penetration of mobile technologies in the health care arena is bound to gain momentum, and as a consequence more physicians will come into contact with that medium; it seems plausible to expect that this development would serve as an impetus for physicians to consider including such technologies into their communication mix with current or future patients.

\section{Macro Driver \#2: The changing physician-patient relationship}

In the advent of the information revolution, the expectations of patients are changing. Changes in information technology, first the Internet and now the mobile medium, are strongly impacting the way physicians interact and communicate with patients, and patients with physicians (Johnson \& Ramaprasad, 2000). Patients increasingly expect to receive more information from their physicians and at the same time to be able to participate in the communication process. The traditional one-way communication from physician to patient is thus evolving from a monologue to a dialogue. The paternalistic, power-dependency model of the physician-patient encounter is changing, particularly by the Internet-driven information revolution (Laing, Hogg, \& Winkelman, 2004). This 
change in the physician-patient relationship may entail changes in the amount and type of information flow and in the level of reciprocity in the relationship (Camacho, Landsman, \& Stremersch, 2010). It may also entail a change in the communication channels used by physicians. A recent study conducted by medTera found that a large majority of patients felt that there was a lack of information and communication between them and their physicians (Comer, 2010) thus echoing similar claims by other authors (e.g. Epstein, Mauksch, Carroll, \& Jaén, 2008). Patients are increasingly looking for and finding relevant medical information on the Internet (Cooley, 2009). Manhattan Research (2010) reports that in the U.S. alone, 99 million adults were found to be "e-empowered" consumers, having either challenged their physician's treatment or diagnosis, asked their physician to change their treatment, discussed information found online at a doctor's appointment, used the Internet instead of going to the doctor, or made a healthcare decision for themselves. The Internet is now the top source of health information for adults in the U.S., outranking their own physicians (Capgemini Consulting, 2011). The access to this information is also facilitated by the rapidly rising use of smart phones that more and more consumers use to go online. In order to heed the demands of "empowered" patients, physicians in private practice might be motivated to increasingly employ the mobile marketing channel into their communication mix.

At the same time, patients are increasingly voicing their opinion about their physicians on rating portals such as HealthGrades.com in the U.S. or Weisse-liste.de in Germany, on patient web communities, or on social media platforms. Consequently, due to the ubiquitous presence of digital media, patients increasingly have the power to significantly affect their physician's image and reputation. In the case of Weisse-liste.de, 37 million insured patients of three major health insurers can rate their physicians along the dimension of "practice and personnel", "physician communication", "treatment" and "general impression" (Gras, 2011). Even though the impact of these rating portals has not been thoroughly analyzed, they constitute a potential explanation to why patient satisfaction is becoming increasingly important to physicians. Just as consumers have become "transparent" due to the availability of purchasing and other data, physicians are equally becoming "transparent" due to the increasing availability of information about their practice and the perceived quality of their services. It would seem reasonable that more transparency requires physicians to better manage their reputation than in the pre-digital and pre-mobile era and mobile technology could contribute to this endeavor.

\section{Macro Driver \#3: Adoption of mobile devices and services}

Physicians have turned into avid adopters of mobile technologies for private and professional purposes. According to recent U.S. market research data (Physicians Interactive, 2010), two-thirds of physicians are now using a mobile device for professional purposes and $70 \%$ of these users indicate that their mobile device is essential to their practice. Physicians' adoption rates of tablet computers, most prominently the iPad, are soaring as well in Europe with $26 \%$ of practicing physicians in Germany, France, Spain and Italy and the UK owning such a device (Tyer, 2012). Physicians use their mobile devices to look up information, browse articles, and to watch videos. In terms of mobile applications physicians make use of medical reference tools, drug information repositories, anatomical maps, medical dictionaries, disease treatments guides to diagnostic lab tools (Jackson \& Coker Research Associates, 2011). Mobile consumption of medical news is increasing rapidly. However, there are significant differences in mobile consumption of medical news between various medical specialties (Healthcare IT News, 2011).

Consumers, and thus current and potential patients, are equally embracing mobile devices enthusiastically. The International Telecommunications Union, (2011) estimates that the global penetration rate of mobile phones has reached $87 \%$ in the developed world and $79 \%$ in the developing world, with $45 \%$ of the world's population covered by a $3 \mathrm{G}$ mobile network which is required for fast mobile Internet access. In the U.S. and Western Europe, $90 \%$ of mobile subscribers own a mobile phone that can access the mobile web (comScore, 2011). It is estimated that by 2015, approximately 500 million people worldwide will be using mobile health applications via smart phones - out of a total audience of 1.4 billion smart phone owners at that point (Murphy, 2010).

\section{MOBILE MARKETING COMMUNICATIONS AND PHYSICIANS IN PRIVATE PRACTICE}

Private practice physicians can, and often already do, pursue a number of marketing communication objectives, using a variety of mobile tools and devices that entail different levels of technological and practical 
complexity. The decision to employ mobile technologies in the communication with current or potential patients is likely to be influenced by a host of different factors on a micro level that should be considered.

\section{Inhibitors and Motivators}

For private physicians to employ the mobile channel as a marketing communication channel, inhibitors and motivators stemming from individual level perceptions regarding marketing, mobile technology, economic and legal considerations are likely to play a key role.

In general, physicians' acceptance and use of a variety of new technologies including mobile devices has been the subject of a significant amount of academic research (e.g. Hu, Chau, Liu Sheng \&Yan Tam, 1999; Chau \& Hu, 2002; Chismar \& Wiley-Patton, 2003; Dixon \& Stewart, 2000; Han, 2005; Han et al., 2006; Park \& Chen, 2007). The Technology Acceptance Model (TAM) is the most widely applied model for user acceptance and usage including the research conducted on physicians (Vatanparast, 2010). In this particular model "perceived usefulness" and "ease-of-use" form a user's attitude towards technology and leads to the intention to use a technology. The general consent of the insights produced by research conducted seems to be that the perceived usefulness of new technologies is one of the key influencing drivers contributing to the adoption and use of new technologies by physicians. Rogers (2003) states that one of the key factors for adoption of an innovation is the innovation's fit with the adopter's values (referred to as Compatibility). These factors may be compatible with the four sets of physician values identified by Kohli \& Kettinger (2004) that include economic values, status values (motivation to be competitive vis-à-vis competitors), altruistic values (desire to put patient's best interest first) and legalistic values (concern of legal consequences). Research of Burley, Scheepers and Fisher (2005) for example seems to indicate that the main adoption decision to buy and use PDAs is made by individual healthcare professionals on a voluntary basis (optional innovation-decision).

However, whereas the above-listed research is relevant and thus applicable to physician's adoption of new technology in general, or mobile technologies and devices in particular, and provides useful insights, the approach of this study is that the decision of a physician in private practice to include the mobile channel into his or her marketing communication will most likely be influenced by a host of additional drivers that need to be explored.

The adoption of a mobile device by a physician for personal or professional use should not be equated with the adoption of the same technology for marketing communication purposes towards current and potential patients. In other words, whereas existing research seems to indicate that physicians as a professional group are avid users of mobile technologies, at the present stage, the mobile channel is just being discovered, albeit slowly, as a marketing or customer relationship channel by this particular group.

\section{Practical considerations}

Physicians in private practice are not expert marketers, and are not expected to be so. As they do not count on a marketing department that could be responsible for conducting mobile marketing activities on an on-going basis, physicians in private practice face the same dilemma as small family-owned companies or start-up companies with limited marketing competences and resources. Physicians work in high stress data intensive environments (SpyGlass Consulting, 2005), usually involving a very large number of patient contacts per week (e.g. Von Borstel, 2010). Hu et al. (1999) suggested that many physicians have little interest in learning about a new technology, even if it is easy to use due to time constraints. In general, the use of the mobile channel as a marketing communication tool has been found to be hindered by the lack of specific competences, the lack of standardization of marketing and mobile technology (Valsecchi, Renga, \& Rangone, 2007) or stemming from limitations of mobile devices themselves including the small screen size and the lack of a standard mobile platform (J.P Morgan, 2010). The lack of a standardized mobile platform for instance refers to the multitude of mobile phone models with different physical and functional designs, screen sizes on the one hand, and technological differences in terms of supported technologies, browser types and operating systems on the other (Gartner, 2011). The degree, to which these obstacles need to be overcome however, will depend on the type of mobile marketing communication used. 
SMS messages for instance do not require an adaptation to a specific operating system, whereas a mobile practice app does. Hence, the level of complexity of mobile marketing communication varies significantly depending on the scope, objectives and tools to be used. As emphasized by Sinisalo, Salo, Karjaluoto \& Leppäniemi (2007), mobile marketers, in this case private practice physicians, must assess their marketing communication capabilities, which include human, technological, and financial resources among others, to ensure that they have the requisite resources to effectively execute the activities related to each of the communications tools and channel. These capabilities will be distributed differently among private practice physicians and will thus contribute to the decision if the mobile channel represents a viable option to communicate with existing and potential patients. As physicians have been found to keep many non-physician clinical tasks to themselves, in order to manage their risk as small business owners (Ludwick \& Doucette, 2009), it is conceivable that these implementation issues are likely to hinge on the capabilities present within a physician's practice, thus limiting the range of mobile marketing activities.

In addition, the decision to use mobile technologies and devices for marketing communication purposes could be influenced by the characteristics of the type of patients seen by the physician. These characteristics include demographics, socio-economic factors, heath insurance coverage, information needs, and perceptions of mobile marketing among others and tend to differ significantly between different physician groups.

\section{Economic considerations}

As physicians in private practice can be perceived to be entrepreneurs managing their own business, economic considerations will play a role in the decision to include mobile marketing communication. In general, a user's perceived return on investment of acquiring new technology and the compatibility of the technology or medium influences the adoption thereof (Rogers, 2003). Specifically, the use of the mobile channel as a marketing communication tool is hindered by the uncertainty of return on investment (Valsecchi et al., 2007). The cost, real or perceived, would include the cost of purchasing the necessary mobile devices or technology, maintenance and personnel or administrative cost. In terms of adoption of electronic health records (EHR) for example, DesRoches et al. (2008) found that financial barriers were viewed as having the greatest effect on decisions about the adoption thereof. However, Friedrich, Gröne, Hölbling \& Peterson (2009) claim that mobile marketing is becoming economically feasible as costs are diminishing. In fact, using mobile technology and devices in their patient-directed communication might be as low as the cost of acquiring an iPad for example.

\section{Individual characteristics and perceptions}

Technology adoption and perception have been correlated with age with younger physicians appearing to be more prone to adopt new mobile technologies for private or professional use (e.g. Bramble et al., 2010; Menachemi, Powers \& Brooks, 2011). As one generation of physicians in private practice retires and a new generation follows, it is conceivable that the overall adoption of mobile technology is poised to increase.

Marketing is still misunderstood, resisted or ignored by many physicians while at the same time physicians have been found to be ill-equipped to deal with changing expectations of their patients (Weinrauch, 1982). At the same time, many physicians feel that they are doing things that they should not be doing (Moores, Wilson, Cave, Woodhead Lyons \& Donoff, 2007). Results of a recent study conducted with physicians in Germany, found that approximately $50 \%$ of physicians rated marketing activities as either very important (16.9\%) or important (33.1\%) and approximately one fifth were of the opinion that today's patients expect some forms of marketing from their practice (Stiftung Gesundheit, 2011).

\section{Legal and privacy issues}

Physicians as a professional group are also severely limited in terms of permissible marketing activities towards their existing or potential patients, facing a plethora of laws and professional limitations regarding marketing and marketing communication activities. In the U.S., state medical boards establish permissible medical marketing statements by physicians, with restrictions varying from state to state. For example, some states entirely forbid the use of patient testimonials (Etna Interactive, n.d.). In the case of Germany for instance, physicians' marketing activities as a professional group are governed by a number of laws and regulations including the Act 
Against Unfair Competition (UWG), the German Medical Products Advertising Act (HWG), and the German Telemedia ACT (TMG) - all of which are summarized in the Professional Code for Physicians (Musterberufsordnung fuer Aerzte - MBO) by the German Medical associations which regulates the ethical and professional obligations of physicians among themselves and vis-à-vis patients. For information provided via the Internet alone, the remote services statutes (Teledienstgesetz (TDG) and the Teleservices Date Protection Act (Telediensdatenschutzgesetz) - (Brandt, 2005; Kassenärztliche Bundesvereinigung, 2010 ). Not surprisingly, uncertainty about what marketing activities are permissible has been shown to be high among physicians in Germany (Stiftung Gesundheit, 2011). Also, security concerns and lack of support have been found to be among the factors limiting the adoption of hand-held computers in healthcare (e.g. Lu, Xiao, Sears \& Jacko, 2005).

\section{Health care system characteristics}

Incentives provided by the health care system in which a physician works are also likely to have an effect of the adoption of mobile technologies. Different health care systems provide different incentives to see more patients and determine the overall economic value that can be achieved by private physicians. These systems in return are strongly influenced by government action in terms of policies, regulations or initiatives related to the adoption of technology, as evidenced in the U.S. in the context of Electronic Health Records (EHRs). Also, within a European context, significant differences exist as discussed for example by Simonet (2010). It is hypothesized that the use of mobile marketing communications by physicians will be different in different health care systems.

\section{Future potential facilitators}

A number of additional facilitators could possibly contribute to a physician's decision to adopt the mobile marketing channel. These incentives, however still theoretical in nature, could include financial incentives from health insures or the government, practical support in the installation and maintenance of mobile systems, training or information sessions among others. The driving forces for these facilitating measures could come from the public sector, health insurers, or the private sectors such as software developers or hardware suppliers. How physicians evaluate these future potential facilitators remains to be investigated.

\section{Mobile marketing objectives for physicians in private practice}

A number of classifications of mobile marketing objectives have been established by academic researchers including Leppäniemi and Karjaluoto (2008), Steimel, Paulke and Klemann (2008) and Pousttchi and Wiedemann (2010). In a physician-patient marketing communication context, possible objectives can be conceived to fall into two broad categories: patient-centered and practice-centered objectives.

\section{Patient-centered objectives}

For communication purposes physicians may distinguish between communication towards current and potential patients. Consequently, patient-centered mobile marketing objectives could be further divided into mobile Customer Relationship Management (mCRM) and mobile advertising and promotion. Mobile CRM can be defined as customer relationship management of any kind including interactive communication between an organization and a customer using a mobile device (Liljander, Polsa \& Forsberg, 2007; Hsu \& Lin, 2008). Directed towards existing patients, mCRM objectives could include relationship building, image building or up-selling. Up-selling in this context could, for instance, refer to offering patients additional services which require an extra payment. CRM activities by physicians make sense as satisfied patients return and may possibly ask for additional services or bring in new patients (Huber, 2010). As customers increasingly expect to be in a position to interact with organizations using different communication channels, Sinisalo et al. (2007) argue that organizations should integrate the mobile channel into their overall customer relationship program while taking advantage of the unique characteristics the medium provides. At the same time, the eventual success of any mobile CRM effort is closely linked with customers' readiness to use existing mobile service (Liljander et al., 2007) and the option of consumer opt-in (e.g. Barnes \& Scornavacca, 2004; Bauer, Reichardt, Barnes \& Neumann, 2005; Leppäniemi \& Karjaluoto, 2005). 
Mobile advertising and promotional activities are directed towards potential patients with the objective to attract potential patients to a physician's practice, distinguishing themselves from competitors. Activities include listings in mobile search pages, physicians' directories, and mobile practice apps or websites. However, as noted above, these activities are usually heavily regulated or restricted by legislation and thus should be examined on a per-country basis.

\section{Practice-centered objectives}

Practice-centered objectives relate to the increase in operational efficiency that has been linked to the inclusion of mobile technologies into the workflow of medical practices. The use of mobile technologies has been suggested to enhance operational efficiency through changing data access patterns (Liang, Huang, Yeh, \& Lin, 2007). This higher operational efficiency could for instance materialize by having fewer patients missing their appointments, making their appointments electronically instead of on the phone, or by making the patient encounter more efficient.

As evidence about the actual effect of the inclusion of mobile technology is rare, we suspect that expectations about potential operational efficiency gains will contribute to a physician's decision to include the mobile channel in the communication with current or potential patients. A word of caution in this context, however, comes from Kassirer (2000) who found that electronic patient-physician communication gives rise to new challenges for physicians, including the inability on the providers' part to manage large message volumes. This factor could be especially important for possible mobile one-on-one marketing communication.

\section{Mobile Tools and Channels for physicians in private practice}

For a physician a number of plausible mobile tools exist for the communication with existing and potential patients. These different mobile tools and solutions are characterized by various degrees of technological and administrative complexity. These tools range from simply using a mobile tablet PC, such as Apple's iPad, as a communication support tool during a consultation with a patient, to maintaining a mobile optimized practice webpage or providing a mobile practice app with a variety of functions to potential and existing patients. An overview of feasible and realistic mobile tools is presented in table 1.

Table 1: Mobile tools and channels for physician's mobile marketing

\begin{tabular}{|l|l|l|}
\hline \multicolumn{1}{|c|}{ Mctivity / Category } & \multicolumn{1}{|c|}{ Mobile Channel } & \multicolumn{1}{c|}{ Description } \\
\hline $\begin{array}{l}\text { Additional Patient } \\
\text { Services }\end{array}$ & Mobile practice app & $\begin{array}{l}\text { Downloadable practice app provides general information including } \\
\text { practice hours, service overview, physician information as well as } \\
\text { complementary tools such as map tool, direct call and email options. }\end{array}$ \\
\hline $\begin{array}{l}\text { Appointment (re)- } \\
\text { scheduling }\end{array}$ & $\begin{array}{l}\text { Mobile web, mobile } \\
\text { practice app }\end{array}$ & $\begin{array}{l}\text { Patients can (re)-schedule appointments via physician's mobile web or by } \\
\text { using mobile practice application. }\end{array}$ \\
\hline $\begin{array}{l}\text { Appointment } \\
\text { reminders }\end{array}$ & $\begin{array}{l}\text { SMS, mobile practice } \\
\text { app }\end{array}$ & $\begin{array}{l}\text { Patients receive a SMS message to their mobile phones or receive a } \\
\text { notification by the mobile practice app to remind them of upcoming } \\
\text { appointment. }\end{array}$ \\
\hline $\begin{array}{l}\text { General information } \\
\text { provision/ patient } \\
\text { education }\end{array}$ & $\begin{array}{l}\text { Mobile web, } \\
\text { narrowcasting }\end{array}$ & $\begin{array}{l}\text { Patients can access general information on premise using internet - } \\
\text { enabled mobile device on local area network or narrowcast for example in } \\
\text { waiting room area of practice. }\end{array}$ \\
\hline $\begin{array}{l}\text { In-consultation } \\
\text { communication } \\
\text { support }\end{array}$ & $\begin{array}{l}\text { Mobile web, mobile } \\
\text { apps }\end{array}$ & $\begin{array}{l}\text { Physician employs mobile device such as a mobile tablet device to look } \\
\text { up information using the mobile web, a mobile app, sharing information } \\
\text { with the patient in written or graphical form. }\end{array}$ \\
\hline $\begin{array}{l}\text { Medication adherence } \\
\text { reminders or alerts }\end{array}$ & SMS, mobile app & $\begin{array}{l}\text { Patients receive personalized reminder or alert via SMS, email message or } \\
\text { alert on mobile practice app. ns with other medication the patient might be } \\
\text { taking. Also suited for medication recall notices from the manufacturer. }\end{array}$ \\
\hline Other Services & SMS & $\begin{array}{l}\text { Patients receive personalized message for birthdays or other personal } \\
\text { events. }\end{array}$ \\
\hline Mobile community & Mobile web page & $\begin{array}{l}\text { Patients interact with each other, posting comments or questions to other } \\
\text { patients on mobile physician or practice web page or social media site. }\end{array}$ \\
\hline Mobile feedback & SMS, mobile web, & Patients send SMS or emails via mobile devices to physician's offices or \\
\hline
\end{tabular}




\begin{tabular}{|c|c|c|}
\hline channel & mobile practice app & post comments or questions on their physician's patient portal. \\
\hline $\begin{array}{l}\text { Mobile newsletters, } \\
\text { blogs }\end{array}$ & $\begin{array}{l}\text { SMS, mobile web, } \\
\text { mobile physician or } \\
\text { patient portal or via }\end{array}$ & $\begin{array}{l}\text { Patients receive physician or practice newsletters, blog updates or other } \\
\text { news in entirety or as link. }\end{array}$ \\
\hline $\begin{array}{l}\text { Mobile Payment } \\
\text { Options }\end{array}$ & $\begin{array}{l}\text { Mobile payment } \\
\text { systems }\end{array}$ & $\begin{array}{l}\text { Patients can make co-payments or payments for costs not covered by } \\
\text { health insurance in physician's office using their mobile phones. }\end{array}$ \\
\hline $\begin{array}{l}\text { Other alerts and } \\
\text { reminders }\end{array}$ & $\begin{array}{l}\text { SMS, email through } \\
\text { mobile web }\end{array}$ & $\begin{array}{l}\text { Patients receive message on their mobile devices, reminding them on } \\
\text { updating necessary vaccinations, periodical routine check-ups, allergy } \\
\text { alerts etc. }\end{array}$ \\
\hline $\begin{array}{l}\text { Patient satisfaction } \\
\text { surveys }\end{array}$ & $\begin{array}{l}\text { Mobile web, On-site } \\
\text { via mobile tablet } \\
\text { computer (ex. iPad). } \\
\text { Off-site via mobile } \\
\text { physician or patient } \\
\text { portal or via email via } \\
\text { mobile web }\end{array}$ & $\begin{array}{l}\text { Patients participate in patient satisfaction or other surveys using a mobile } \\
\text { tablet computer provided by the physician or staff in the practice, access } \\
\text { online surveys via their mobile phones while waiting in physician practice } \\
\text { or from any other location. }\end{array}$ \\
\hline $\begin{array}{l}\text { Post-consultation } \\
\text { support }\end{array}$ & $\begin{array}{l}\text { Mobile physician web } \\
\text { portal, patient portal, } \\
\text { mobile app, SMS }\end{array}$ & $\begin{array}{l}\text { Physician uses mobile device for documentation. Patients access online } \\
\text { information provided by physicians on mobile webpage, physician or } \\
\text { patient portal, or using physician recommended mobile apps on their } \\
\text { mobile device. }\end{array}$ \\
\hline $\begin{array}{l}\text { Pre-consultation } \\
\text { support }\end{array}$ & $\begin{array}{l}\text { Mobile apps, access to } \\
\text { patient data via mobile } \\
\text { device, mobile } \\
\text { administrative } \\
\text { solutions }\end{array}$ & $\begin{array}{l}\text { Physician uses mobile device, mobile app or mobile administrative } \\
\text { software to review patient data before the consultation. }\end{array}$ \\
\hline \multicolumn{3}{|c|}{ Mobile Advertising and Promotion } \\
\hline Mobile advertising & $\begin{array}{l}\text { Mobile web, Mobile } \\
\text { practice app, QR code }\end{array}$ & $\begin{array}{l}\text { Physician uses mobile advertising formats (e.g. banner ads) to advertise } \\
\text { practice or services in relevant mobile web pages, ideally providing link } \\
\text { to physician or practice webpage. Application of QR code on physician's } \\
\text { practice sign or on other communication material. }\end{array}$ \\
\hline Mobile search & $\begin{array}{l}\text { Mobile (physician) } \\
\text { search pages, } \\
\text { directories }\end{array}$ & $\begin{array}{l}\text { Physician lists practice and service information on specific mobile } \\
\text { physician search portals. }\end{array}$ \\
\hline Viral marketing & SMS, mobile web & $\begin{array}{l}\text { Physician sends out information to existing patients in form of newsletters } \\
\text { or blogs, via SMS for example, that may be passed on to via a mobile } \\
\text { device. }\end{array}$ \\
\hline
\end{tabular}

\section{CONCLUSIONS AND FUTURE RESEARCH AVENUES}

As Grant (2008) states, we are at the threshold of a mobile revolution that has the potential to revolutionize society. As mobile technologies present marketers of all specializations with new and in many ways, unique possibilities to communicate with their chosen target audience, there is no doubt that they will impact profoundly the way physicians communicate with existing and potential patients in the future. However, if mobile marketing as a research topic has been considered to be still in its infancy (Varnali \& Toker, 2010), then we could argue that mobile marketing for physicians as a research topic is still in its embryonic stage.

As discussed in this paper, the emergence of the mobile channel for marketing purposes provides for a number of opportunities for marketers in general and for physicians in private practice in particular. Although existing research on the general topic of mobile marketing has made significant inroads on shedding light to the general understanding of the issues related to mobile marketing, a number of research questions in the abovediscussed context remain to be investigated. Specifically, the following research questions would assist in furthering the academic and practical knowledge in this context. What are the factors that contribute to a physician's decision to employ mobile technology in their communication towards existing and potential patients? Likewise, what are the factors that represent detriments to the actual implementation and use of the mobile channel in the communication process of physicians with existing and potential patients? Given the premise that the use of mobile technologies in the physician-patient communication could be mutually beneficial situation, what are the factors that would make physicians adopt mobile technologies for this purpose? What are the "enabling" factors in this context? In which 
practical areas do physicians perceive the greatest future potential for mobile technologies? In other words, where does the future for mobile technologies and applications lie in the physician-patient context? What are the experiences with mobile technologies for said purpose by the "pioneers" - those physicians who already use it in their practice and thus what are the strengths and weaknesses of mobile technology from the perspective of physicians?

\section{AUTHOR INFORMATION}

Peter M. Resch is a Ph.D. candidate at the IQS School of Management and visiting lecturer at the University of Wisconsin in Milwaukee. His academic research in the mobile marketing field focuses on the physician-patient communication. He holds a BBA in International Marketing from Baruch College in New York, an MBA from ESADE Business School in Barcelona and a Master of Research degree from the IQS School of Management. Mailing Address: 1915 E Kennilworth Place, \#637, Milwaukee, WI, USA. E-mail: peterresch@iqs.edu (Corresponding author)

Dr. Marta Tena is a professor at the IQS School of Management. Her academic research focuses on Integrated Marketing Communications in a variety of industries around the globe. Dr. Tena holds a Ph.D. in Business Administration from Universitat Ramón Llull and a Bachelors' degree in Communication Sciences from Universitat Autònoma de Barcelona, Spain. Mailing Address: Via Augusta, 390, 08017, Barcelona, Spain. E-mail: marta.tena@iqs.edu

\section{REFERENCES}

1. Arnold, M. (2011, January 14). Patient Education Report: Class apps. Medical Marketing \& Media. Retrieved from http://www.mmm-online.com/patient-education-report-class-apps/article/194925/

2. Avery, E.J. (2010). The role of source and the factors audiences rely on in evaluating credibility of health information. Public Relations Review, 36(1), 81-83. doi: 10.1016/j.pubrev.2009.10.015

3. Barnes, S. J. \& Scornavacca, E. (2004). Mobile marketing: The role of permission and acceptance. International Journal of Mobile Communications, 2(2), 128-139. doi: 10.1504/IJMC.2004.004663

4. Barwise, P. \& Strong, C. (2002). Permission-based mobile advertising. Journal of Interactive Marketing, 16(1), 14-24. doi: 10.1002/dir.10000

5. Bauer, H. H., Reichardt, T., Barnes, S. J., \& Neumann, M. M. (2005). Driving consumer acceptance of mobile marketing: A theoretical framework and empirical study. Journal of Electronic Commerce Research, 6(3), 181-192.

6. BenMoussa, C. (2010). Investigating enablers of sea success: Case study of a pharmaceutical company. Journal of Information Technology Case and Application Research, 12(1), 57-86.

7. Bramble, J. D., Galt, K. A., Siracuse, M. V., Abbott, A. A., Drincic, A., Paschal, K. A. \& Fuji, K. T. (2010). The relationship between physician practice characteristics and physician adoption of electronic health records. Health Care Management Review, 35(1), 55-64. doi: 10.1097/HMR.0b013e3181c3f9ad

8. Brandt, O. (2005). Ärzte-Marketing im Internet [Physician marketing in the Internet]. In V. Streit and M. Letter (Eds.), Marketing für Arztpraxen [Marketing for physician's practices] (pp. 161-170). Berlin, Germany: Springer.

9. Burley, L., Scheepers, H. \& Fisher, J. (2005). Diffusion of mobile technology in healthcare. Proceedings of EURO Mgov 2005, 67-76. Retrieved from http://www.mgovernment.org/resurces/euromgov2005/PDF/8_R356BL.pdf

10. Capgemini Consulting (2011). Patient Adherence: The next frontier in patient care - vision and reality (9th ed.). Retrieved from http://www.capgemini.com/m/en/t1/Patient_Adherence The Next_Frontier_in_Patient_Care.pdf

11. Camacho, N., Landsman, V. \& Stremersch, S. (2010). The connected patient. In: S. Wuyts, M.G Dekimpe, E. Gijsbrechts and R. Pieters (Eds.), The connected customer: The changing nature of consumer and business markets (pp. 107-140). Hove, UK: Routledge.

12. Chau, P.Y.K. \& Hu, P. J-H. (2002). Investigating healthcare professionals' decision to accept telemedicine technology: An empirical test of competing theories. Information and Management, 39(4), 297-311. 
13. Chismar, W.G. \& Wiley-Patton, S. (2003). Does the extended technology acceptance model apply to physicians? Proceedings of the 36th Hawaii International Conference on System Sciences. USA. doi: 10.1109/HICSS.2003.1174354

14. comScore (2011, February 14). The 2010 mobile year in review. Retrieved from http://www.comscore.com/Press_Events/Presentations_Whitepapers/2011/2010_Mobile_Year_in_Review

15. Comer, B. (2010, December 15). Info-starved patients want more from docs, survey says. Medical Marketing \& Media. Retrieved from http://www.mmm-online.com/info-starved-patients-want-more-fromdocs-survey-says/article/192856/

16. Cooley, D.O. (2009). How did you find your physician? International Journal of Pharmaceutical and Healthcare Marketing, 3(1), 46-58. doi: 10.1108/17506120910948502

17. Cruz, P., Filgueiras Neto, L.B., Muñoz-Gallego, P. \& Laukkanen, T. (2010). Mobile banking rollout in emerging markets: Evidence from Brazil. International Journal of Bank Marketing, 28(5), 342-371. doi: 10.1108/02652321011064881

18. Dai, H. and Palvia, P.C. (2009). Mobile commerce adoption in China and the United States: A crosscultural study. ACM SIGMIS Database, 40(4), 43-61. doi: 10.1145/1644953.1644958

19. DesRoches, C.M., Campbell, E.G., Rao, S.R, Donelan, K., Ferris, T.G., Jha, A., ...Blumenthal, D. (2008). Electronic Health Records in ambulatory care - a national survey of physicians. New England Journal of Medicine, 359(1), 50-60. doi: 10.1056/NEJMsa0802005

20. Dixon, D.R. \& Stewart, M. (2000). Exploring information technology adoption by family physicians: Survey instrument valuation. Proceedings of the American Medical Informatics Association Symposium 2000, 185 -189. Retrieved from http://www.ncbi.nlm.nih.gov/pubmed/11079870

21. Drossos, D. \& Giaglis, G.M. (2010). Reviewing mobile marketing research to date: Towards ubiquitous marketing. In K. Pousttchi \& D. Wiedemann, D. (Eds.), Handbook of Research on Mobile Marketing Management (pp. 10-36). Hershey, PA: Business Science Reference.

22. Epstein, R.M., Mauksch, L., Carroll, J. \& Jaén, C.R. (2008). Have you really addressed your patient's concerns? Family Practice Management, 15(3), 35-40.

23. Etna Interactive (n.d.). Highlights of medical marketing laws. Retrieved from http://www.etnainteractive.com/learning-center/medical-marketing-law/

24. Friedrich, R., Gröne, F., Hölbling, K. \& Peterson, M. (2009). The march of mobile marketing: New chances for consumer companies, new opportunities for mobile operators. Journal of Advertising Research, 49(1), 54-61. doi: 10.2501/S0021849909090096

25. Gartner (2011, June 16). Gartner says worldwide mobile advertising revenue forecast to reach $\$ 3.3$ billion in 2011.[Press release]. Retrieved from http://www.gartner.com/it/page.jsp?id=1726614

26. Gehring, W.G. \& Gehring, M. (2005). Drahtseilakt zwischen Ethik und Business [Balancing act between ethics and business]. In V. Streit \& M. Letter (Eds.), Marketing für Arztpraxen (pp. 91-116). Berlin, Germany: Springer.

27. Goldberg, S. \& Wickramasinghe, N. (2003). 21st century healthcare - the wireless panacea. Proceedings of the 36th Annual Hawaii International Conference on System Sciences, USA.

doi: 10.1109/HICSS.2003.1174360

28. Grant, A.E. (2008). The mobile revolution. In A. E. Grant \& J. Harmon Meadows (Eds.), Communication Technology Update and Fundamentals (11th ed., pp. 343-350). Burlington, MA: Focal Press.

29. Gras, H.J. (2011, May 6). Online-Reputation-Management für Ärzte: Zweimal täglich [Online reputation management for physicians: Twice daily] [Web log post]. Retrieved from http://www.reputationmanagement-blog.de/2011/05/06/online-reputation-management-fur-arzte-zweimal-taglich/

30. Han, S. (2005). Understanding user adoption of mobile technology: Focusing on physicians in Finland. [Doctoral dissertation, Abo Akademi]. Available from ProQuest Dissertations \& Theses (PQDT) database. (C823849)

31. Han, S., Mustonen, P., Seppänen, M. \& Kallio, M. (2006). Physicians' acceptance of mobile communication technology: An exploratory study. International Journal of Mobile Communications, 4(2), 210-230. doi: 10.1504/IJMC.2006.008610

32. Healthcare IT News (2011, April 7). Physician mobile use grows 45 percent. Retrieved from http://www.healthcareitnews.com/news/physician-mobile-use-grows-45-percent

33. Hsu, C.F. \& Lin, S. (2008). mCRM's new opportunities of customer satisfaction. International Journal of Human and Social Sciences, 3(2), 133-137. 
34. Hu, P., Chau, P.Y.K, Liu Sheng, O.R., Yan Tam, K. (1999.) Examining the technology acceptance model using physician acceptance of telemedicine technology. Journal of Management Information Systems, 16 (2), 91-112.

35. Huber, I. (2010). Warum ist CRM sinnvoll und effizient? [Why is CRM sensible and efficient?] PMReport. Retrieved from http://www.pm-report.de/newsletter/pdf/2010_11/_direktmarketing2.pdf

36. International Telecommunications Union (2011). The world in 2011- facts and figures. Retrieved from http://www.itu.int/ITU-D/ict/facts/2011/material/ICTFactsFigures2011.pdf

37. Istepanian, R.S.H. \& Lacal, J.C. (2003). Emerging mobile communication technologies for health: Some imperative notes on m-health. Proceedings of the 25th Annual International Conference of the IEEE Engineering in Medicine and Biology Society, 1414-1416. doi: 10.1109/IEMBS.2003.1279581

38. Jackson \& Coker Research Associates (2011). Special report: Apps, doctors, and digital devices. Retrieved from http://www.jacksoncoker.com/physician-career-resources/newsletters/monthlymain/des/Apps.aspx

39. Johnson, G.L. \& Ramaprasad, A. (2000). Patient-physician relationships in the information age. Marketing Health Services, 20(1), 20-27.

40. Jokela, J., Han, S., Harkke, V., Kallio, M., Lindgren, L \& Castrèn, M. (2009). A comparison study of using a mobile medical information system. Journal of Systems and Information Technology, 11(3), 286-294. doi: $10.1108 / 13287260910983641$

41. J.P Morgan (2010, June 4). Mobile Advertising: An in-depth look at the future of mobile advertising. Retrieved from https://mm.jpmorgan.com/stp/t/c.do?i=E8283-B8\&u=a_p*d 423260.pdf*h 2tvncakf

42. Kassenärztliche Bundesvereinigung (2010). Marketing in der Arztpraxis Teil II: Rechtliche Grundlagen [Marketing in the physician practice part II: Legal foundations]. Retrieved from http://www.kbv.de/service/6508.html

43. Kassirer, J.P. (2000). Patients, physicians, and the Internet. Health Affairs 19(6), 115-124. doi: 10.1377/hlthaff.19.6.115

44. Kohli, R., \& Kettinger, W. (2004). Informating the clan: Controlling physicians' costs and outcomes. MIS Quarterly, 28(3), 363-394.

45. Laing, A., Hogg, G. \& Winkelman, D. (2004). Health care and the information revolution: Re-configuring the healthcare service encounter. Health Services Management Research. 17(3), 188-199. doi: $10.1258 / 0951484041485584$

46. Leppäniemi, M. \& Karjaluoto, H. (2005). Factors influencing consumers' willingness to accept mobile advertising: A conceptual model. International Journal of Mobile Communications, 3(3), 197-213. doi: 10.1504/IJMC.2005.006580

47. Leppäniemi, M. \& Karjaluoto, H. (2008). Mobile marketing: From marketing strategy to mobile marketing campaign implementation. International Journal of Mobile Marketing, 3(1), 50-62.

48. Letter, M. (2005). Der Patient wird zum Kunden [The patient becomes a customer]. In V. Streit \& M. Letter (Eds.), Marketing für Arztpraxen (pp. 1 - 28). Berlin, Germany: Springer.

49. Liang, T.-P., Huang, C.-W., Yeh, Y.-H., \& Lin, B. (2007). Adoption of mobile technology in business: A fit-viability model. Industrial Management \& Data Systems, 107(8), 1154-1169. doi: 10.1108/02635570710822796

50. Liljander, V., Polsa, P., \& Forsberg, K. (2007). Do mobile CRM services appeal to loyalty program customers?. International Journal of E-Business Research (IJEBR), 3(2), 24-40. doi:10.4018/jebr.2007040103

51. Lu, Y. C., Xiao, Y., Sears A. \& Jacko, J. A. (2005). A review and a framework of handheld computer adoption in healthcare. International Journal of Medical Informatics, 74(5), 409-422.

52. Ludwick, D.A. \& Doucette, J. (2009). Improve office efficiency by putting your patients to work: Patients' perspectives regarding online self-service appointment scheduling in family practice. Electronic Healthcare, 8(4), 17-20.

53. Manhattan Research (2010, November 9). 99 million e-empowered consumers are using online information and tools to take a more active role in their healthcare. Retrieved from http://manhattanresearch.com/News-and-Events/Press-Releases/e-empowered-patients-use-online-healthinfo 
54. Menachemi, N., Powers, T. L. \& Brooks, R. G. (2011). Physician and practice characteristics associated with longitudinal increases in electronic health records adoption. Journal of Healthcare Management, 56(3), 183-197.

55. Mobile Marketing Association (2008). MMA Glossary. Retrieved from http://mmaglobal.com/wiki/mobilemarketing

56. Moores, D.G., Wilson, D.R., Cave, A.J., Woodhead Lyons, S.C. \& Donoff, M.G. (2007). Improving the quality and capacity of Canada's health services: Primary care physicians' perspectives. Healthcare Policy. 3(2), 145-161.

57. Murphy, D. (2010). 500m using mobile health apps by 2015. Mobile Marketing Magazine. Retrieved from: http://www.mobilemarketingmagazine.co.uk/content/500m-using-mobile-health-apps-2015

58. Park, Y. \& Chen, J.V. (2007). Acceptance and adoption of the innovative use of smartphone. Industrial Management Data Systems, 107(9), 1349-1365. doi: 10.1108/02635570710834009

59. Physicians Interactive (2010). 4 reasons mobile marketing should be a part of your next campaign. Retrieved from http://www.physiciansinteractive.com/market-

flash/four_reasons mobile marketing pharma_campaign

60. Pousttchi, K. \& Wiedemann, D. (2010). Mobile marketing management: Marketing objectives, types and implementation techniques. In: K. Pousttchi \& D. Wiedemann (Eds.), Handbook of Research on Mobile Marketing Management (pp. 1-9). Hershey, PA: Business Science Reference.

61. Riivari, J. (2005). Mobile banking: A powerful new marketing and CRM tool for financial services companies all over Europe. Journal of Financial Services Marketing, 10(1), 11-20. doi:

10.1057/palgrave.fsm.4770170

62. Rogers, E. (2003). Diffusion of Innovations (5th ed.). New York, NY: Free Press.

63. Scornavacca, E., Huff, S. \& Marshall, S. (2009). Mobile phones in the classroom: If you can't beat them, join them. Communications of the ACM, 52(4), 142-146. doi: 10.1145/1498765.1498803

64. Shankar, V. \& Balasubramanian, S. (2009). Mobile marketing: A synthesis and prognosis. Journal of Interactive Marketing, 23(2), 118-129. doi: 10.1016/j.intmar.2009.02.002

65. Shankar, V., Venkatesh, A., Hofacker, C. \& Naik, P. (2010). Mobile marketing in the retailing environment: Current insights and future research avenues. Journal of Interactive Marketing, 24(2), 111120. doi: 10.1016/j.intmar.2010.02.006

66. Sharma, C., Herzog, J. \& Melfi, V. (2008). Mobile Advertising. Hoboken, NJ: John Wiley \& Sons.

67. Simonet, D. (2010). Healthcare reforms and cost reduction strategies in Europe: The cases of Germany, UK, Switzerland, Italy and France. International Journal of Health Care Quality Assurance, 23(5), 470488 .

68. Sinisalo, J., Salo, J., Karjaluoto, H. \& Leppäniemi, M. (2007). Mobile customer relationship management: Underlying issues and challenges. Business Process Management Journal, 13(6), 771-787. Doi: $10.1108 / 14637150710834541$

69. SpyGlass Consulting (2005). Healthcare without Bounds: Mobile computing for physicians. [Abstract]. Retrieved from http://www.spyglassconsulting.com/Abstracts/Spyglass_Mobile_Computing for_Physicians.v1.6.pdf

70. Steimel, B., Paulke, S. \& Klemann, J. (2008). Praxisleitfaden Mobile Marketing. Mehrbusch, Germany: mind Business Consultants.

71. Stiftung Gesundheit (2011). Ärzte im Zukunftsmarkt Gesundheit [Physicians in the market of the future]. Retrieved from http://www.stiftunggesundheit.de/PDF/studien/Aerzte_im_Zukunftsmarkt_Gesundheit_2011_Kurzfassung. pdf

72. Sultan, F. \& Rohm, A. (2005). The coming era of "brand in the hand" marketing. MIT Sloan Management Review, 47(1), 82-90.

73. Tyer, D., (2012, February 15). Twenty six per cent of European doctors own an iPad. [Web log post]. Retrieved from http://www.pmlive.com/digital_intelligence_blog/archive/2012/feb_2013/european_doctors_ipad_use_own ership

74. Valsecchi, M., Renga, F.M. \& Rangone, A. (2007). Mobile customer relationship management: An exploratory analysis of Italian applications. Business Process Management Journal, 13(6), 755-770. doi: $10.1108 / 14637150710834532$ 
75. Van Doren, D.C. \& Blank, K.M. (1992). Patient education: A potential marketing tool for the private physician. Journal of Health Care Marketing, 12 (1), 71-77.

76. Varnali, K. \& Toker, A. (2010). Mobile marketing research: The-state-of-the-art. International Journal of Information Management, 30(2), 144-151. doi: 10.1016/j.ijinfomgt.2009.08.009

77. Vatanparast, R. (2010). Theories behind mobile marketing research. In: K. Pousttchi \& D. Wiedemann (Eds.). Handbook of Research on Mobile Marketing Management (pp. 255 - 278). Hershey, PA: Business Science Reference.

78. Von Borstel, S. (2010, January 19). Deutsche gehen weltweit am häufigsten zum Arzt [Germans visit physicians most frequently in the world]. Die Welt. Retrieved from http://www.welt.de

79. Wang, H.Y. \& Wang, S.H. (2010). Predicting mobile hotel reservation adoption: Insight from a perceived value standpoint. International Journal of Hospitality Management, 29(4), 598-608. Retrieved from http://linkinghub.elsevier.com/retrieve/pii/S0278431909001510

80. Weinrauch, J.D. (1982). The entrepreneurial physician: Marketing challenges and opportunities. Journal of Small Business Management, 20(2), 8-14.

81. West, J. \& Blankenship, A. (1975). The physician and the marketing concept. Journal of the Academy of Marketing Science, 3(2), 137-147. doi: 10.1007/BF02729525

82. Winer, R.S. (2009). New communications approaches in marketing: Issues and research directions. Journal of Interactive Marketing, 23(2), 108-117. doi: 10.1016/j.intmar.2009.02.004

83. World Health Organization (2011). mHealth: New horizons for health through mobile technologies: Second global survey on eHealth. Retrieved from http://whqlibdoc.who.int/publications/2011/9789241564250_eng.pdf 


\section{NOTES}

